\title{
A REVIEW ON THE RELATIONSHIP BETWEEN OIL PRICES AND STOCK PRICES IN TURKEY: NEW EVIDENCES FROM FOURIER APPROACH
}

\author{
Türkiye'de Petrol Fiyatları ile Hisse Senedi Fiyatları Arasındaki İlişki Üzerine Bir \\ Inceleme: Fourier Yaklaşımından Yeni Kanıtlar
}

\section{Mehmet SONGUR}

Keywords:

Oil Prices, Stock

Prices, Fourier

Analysis

JEL Codes:

F65, Q43, C58

Anahtar Kelimeler:

Petrol Fiyatlar1, Hisse

Senedi Fiyatları,

Fourier Analizi

JEL Kodları:

F65, Q43, C58

\begin{abstract}
Oil is one of the most important energy resources in production and consumption processes. Therefore, shocks from oil prices can affect many macroeconomic variables. One of these macroeconomic variables is stock prices, and it is important to investigate the long-term relationship between the two variables. The purpose of this study is to test the long-term existence of a relationship between oil prices and BIST100 index in Turkey by making use of data collected on daily basis between a period of 02/01/2002 and 02/07/2019. Within this context, Fourier stationarity and Fourier cointegration tests were utilized since they take into account both sharp and gradual/smooth structural breaks. Findings of the analysis indicate that there is not a long-term cointegration relationship between oil prices and stock prices under both sharp and gradual/smooth structural breaks. Regarding the findings in this context, it can be inferred that changes in oil prices are not to be effective on the share prices in Turkey.
\end{abstract}

\section{Özet}

Petrol, üretim ve tüketim süreçleri içerisinde en önemli enerji kaynaklarından birisidir. $\mathrm{Bu}$ nedenle petrol fiyatlarında meydana gelen şoklar birçok makro ekonomik değişkeni etkileyebilmektedir. Söz konusu makro ekonomik değişkenlerden birisi de hisse senedi fiyatları olup, iki değişken arasındaki uzun dönemli ilişkiyi araştırmak önem arz etmektedir. Bu çalışmanın amacı, 02/01/2002 - 02/07/2019 tarihleri arasında günlük olarak toplanan verilerden yararlanarak Türkiye'de petrol fiyatları ile BIST100 endeksi arasındaki ilişkinin uzun vadede varlığını test etmektir. Bu bağlamda, çalışmada hem keskin hem de aşamalı / yumuşak yapısal kırılmaları hesaba kattıkları için Fourier durağanlık ve Fourier eşbütünleşme testleri kullanılmıştır. Analizin bulguları, hem keskin hem de aşamalı / yumuşak yapısal kırılmalar altında petrol fiyatları ile hisse senedi fiyatları arasında uzun vadeli bir eşbütünleşme ilişkisi olmadığını göstermektedir. Bu bağlamda bulgulara bakıldığında, petrol fiyatlarındaki değişimlerin Türkiye'deki hisse senedi fiyatları üzerinde etkili olmadığı söylenebilir.

\footnotetext{
* The first version of this study was presented in the 20th National Economics Symposium of Turkish Economy Institution.

** Assist. Prof. Dr., Dicle University, Faculty of Economics and Administrative Sciences, Department of Economics, mehmet.songur@dicle.edu.tr, ORCID: 0000-0003-4763-9314
}

Makale Geliş Tarihi (Received Date): 12.10.2020 Makale Kabul Tarihi (Accepted Date): 5.03.2021 


\section{Introduction}

Oil, as one of the main energy resources, is a significant input for all sectors, directly or indirectly. In 2018, the average daily oil consumption in the world is 99843 barrels and the share of oil consumption in all energy sources is approximately 33\% (British Petroleum [BP], 2019). Therefore, increases in oil prices, which are an essential input in the production process, increase uncertainty and lead to negative effects on wealth and investment (Maghyereh and AlKandari, 2007, p. 450). Therefore, many macroeconomic variables are adversely affected by the volatility in oil prices.

There were significant increases in oil prices in certain periods. In 1973, there occurred the first oil shock, due to the embargo imposed by OPEC (Organization of Petroleum Exporting Countries). In 1979, the Iranian Revolution caused the second oil shock. Just after these two oil shocks, studies focusing on the relationship between oil prices and macroeconomic variables were contributed to the literature (Burbidge and Harrison, 1984; Gisser and Goodwin, 1986; Hamilton, 1983). Afterwards, an excessive volatility was observed in oil prices during the IranIraq War, started in 1980, the Gulf War in 1990, the Asian Crisis in 1998, the Invasion of Iraq in 2003, Global Crisis in 2008, and the Arab Spring in 2010. All these developments have kept alive the examination of the relationship between oil prices and macroeconomic variables.

Oil, like capital and labor, is an important input used directly or indirectly in the production process in all sectors. As the increasing volatility in oil prices results in uncertainty, it also affects cash flows. When oil prices increase, production costs will increase if oil is not substitutable. Therefore, cash flow will decrease and this will trigger stock prices to fall. However, the increase in oil prices causes inflation to increase and the central banks raise interest rates. High interest rates make bonds more attractive rather than falling stocks. Additionally an increase in oil prices depends on whether the companies are producers or consumers of petroleum and petroleum products. Since oil-producing companies are less than oil consuming companies in the world, the increase in oil prices may have negative effects on stock prices (Basher and Sadorsky, 2006, p. 225-226).

The motivation of this study is to investigate the long-term relationship between stock prices and oil prices. In this context, it is to make suggestions to both investors and policy makers. With this motivation, the purpose of this study is to examine the impact of oil prices on stock prices in Turkey, utilizing Fourier SHIN cointegration test, contributed to the literature by Tsong, Lee, Tsai and Hu (2016). In this context, daily data for the period between 02/01/2002 and 02/07/2019 were used. The advantage of the Fourier SHIN Cointegration test over other tests in the literature is that it examines the long-term relationship between two variables, taking into account sharp structural breaks as well as smooth structural breaks. Since our study examines the relationship between stock prices and oil prices on daily data using Fourier approach, it is of importance to contribute to the literature.

The organization of this paper is as follows. In section 2 is presented the relevant literature. In section 3, we introduce econometric methodology used in the study. In section 4, data will be explained first and the empirical findings will be discussed later. In section 5, the findings obtained from the analysis will be examined and discussed. 


\section{Literature Review}

A summary of the studies examining the relationship between stock prices and oil prices is presented in Table 1. Within an overall perspective, it can be inferred that there exists a relationship between oil prices and stock prices. In particular, it can be emphasized that shocks in oil prices have significant impact on stock prices. However, Apergis and Miller (2009), Arouri, Bellalah and Nguyen (2011), Çıtak and Kendirli (2019), Gay (2008) and İşcan (2010) provide evidences that there is no relationship between oil prices and stock prices.

Table 1. Literature Review

\begin{tabular}{|c|c|c|c|}
\hline Author(s) & Period and method & Countries & Results \\
\hline $\begin{array}{l}\text { Sadorsky } \\
(1999)\end{array}$ & $\begin{array}{l}\text { 1947: M1 - 1996: } \\
\text { M4, } \\
\text { VAR Model }\end{array}$ & USA & $\begin{array}{l}\text { Movements in crude oil prices exhibit negative } \\
\text { behavior in the stock market. }\end{array}$ \\
\hline $\begin{array}{l}\text { Marghyereh } \\
\text { and Al- } \\
\text { Kandari } \\
(2007)\end{array}$ & $\begin{array}{l}\text { 1996: M1 - 2003: } \\
\text { M12, } \\
\text { Nonlinear } \\
\text { Cointegration Test }\end{array}$ & Gulf Countries & $\begin{array}{l}\text { There is a nonlinear relationship between the } \\
\text { two variables. }\end{array}$ \\
\hline $\begin{array}{l}\text { Cong, Wei, } \\
\text { Jiao and Fan } \\
(2008)\end{array}$ & $\begin{array}{c}\text { 1996: M1 - 2007: } \\
\text { M12, } \\
\text { VAR Model }\end{array}$ & China & $\begin{array}{l}\text { Shocks in oil prices do not have a significant } \\
\text { impact on stock prices. }\end{array}$ \\
\hline $\begin{array}{l}\text { Gay } \\
(2008)\end{array}$ & $\begin{array}{l}\text { 1999-2006 } \\
\text { (Montly data), } \\
\text { Box-Jenkins } \\
\text { ARIMA Model }\end{array}$ & $\begin{array}{c}\text { BRIC } \\
\text { Countries }\end{array}$ & $\begin{array}{l}\text { There is no relationship between the two } \\
\text { variables. }\end{array}$ \\
\hline $\begin{array}{l}\text { Park and Ratti } \\
\text { (2008) }\end{array}$ & $\begin{array}{l}\text { 1986: M1 - } \\
\text { 2005:M12, } \\
\text { VAR Model }\end{array}$ & $\begin{array}{l}\text { USA and } 13 \\
\text { European } \\
\text { Countries }\end{array}$ & $\begin{array}{l}\text { Shocks in crude oil prices cause negative } \\
\text { shocks on real stock returns. }\end{array}$ \\
\hline $\begin{array}{l}\text { İşcan } \\
(2010)\end{array}$ & $\begin{array}{l}3 \text { December } 2001- \\
31 \text { December } 2009, \\
\text { Johansen } \\
\text { Cointegration }\end{array}$ & Turkey & $\begin{array}{l}\text { There is no long-term cointegration } \\
\text { relationship between the two variables. }\end{array}$ \\
\hline $\begin{array}{l}\text { Arouri et al. } \\
\qquad(2011)\end{array}$ & $\begin{array}{l}\text { 1999: M1-2009: } \\
\text { M9, } \\
\text { VAR Model and } \\
\text { Cointegration }\end{array}$ & Gulf Countries & $\begin{array}{l}\text { There is a short-term positive effect between } \\
\text { the two variables. In the long run, however, } \\
\text { there was no relationship between the two } \\
\text { variables. (except for Bahrain). }\end{array}$ \\
\hline $\begin{array}{l}\text { Broadstock, } \\
\text { Cao and Zhang } \\
\quad(2012)\end{array}$ & $\begin{array}{c}\text { January } 2000-\text { May } \\
2011 \text { (Weekly data), } \\
\text { Time Varying } \\
\text { Conditional } \\
\text { Correlations }\end{array}$ & China & $\begin{array}{l}\text { International oil prices affect the stock returns } \\
\text { in the energy sector }\end{array}$ \\
\hline $\begin{array}{l}\text { Ünlü and } \\
\text { Topcu } \\
(2012)\end{array}$ & $\begin{array}{c}\text { 1990-2011 } \\
\text { Johansen } \\
\text { Cointegration, VEC } \\
\text { and Toda- } \\
\text { Yamamoto } \\
\text { Causality }\end{array}$ & Turkey & Oil prices positively affect the stock market. \\
\hline $\begin{array}{l}\text { Şener, Y1lancı } \\
\text { and Tiraşoğlu } \\
\text { (2013) }\end{array}$ & $\begin{array}{c}\text { 2002-2012 (Daily } \\
\text { data), } \\
\text { Hidden } \\
\text { Cointegration } \\
\end{array}$ & Turkey & $\begin{array}{l}\text { There is a long-term relationship between the } \\
\text { two variables. }\end{array}$ \\
\hline $\begin{array}{l}\text { Cunado and } \\
\text { Gracia (2014) }\end{array}$ & $\begin{array}{c}\text { 1973: M2-2011: } \\
\text { M12 } \\
\text { VAR and VEC } \\
\text { Model }\end{array}$ & $\begin{array}{l}12 \text { European } \\
\text { Countries }\end{array}$ & $\begin{array}{l}\text { Stock prices are due to shocks in oil prices and } \\
\text { are negatively affected. }\end{array}$ \\
\hline
\end{tabular}


Table 1...

\begin{tabular}{|c|c|c|c|}
\hline $\begin{array}{l}\text { Le and Chang } \\
\qquad(2015)\end{array}$ & $\begin{array}{c}\text { 1997: M1 - } \\
\text { 2013:M7, Gregory } \\
\text { Hansen and Toda } \\
\text { Yamamoto }\end{array}$ & $\begin{array}{l}\text { Malaysia, } \\
\text { Singapore and } \\
\text { Japan }\end{array}$ & $\begin{array}{l}\text { Increases in oil prices have different effects on } \\
\text { stock prices in different markets and periods. }\end{array}$ \\
\hline $\begin{array}{l}\text { Abdullah, Saiti } \\
\text { and Masih } \\
\quad(2016)\end{array}$ & $\begin{array}{l}2007-2014 \\
\text { (Daily data), } \\
\text { MGARCH-DCC } \\
\text { and Wavelet } \\
\text { Approaches }\end{array}$ & $\begin{array}{l}\text { Malaysia, } \\
\text { Thailand, } \\
\text { Singapore, } \\
\text { Phillippine } \\
\text { and Indonesia }\end{array}$ & $\begin{array}{l}\text { In the study, which examined the relationship } \\
\text { between Islamic stocks and oil prices, it was } \\
\text { observed that both variables had less } \\
\text { correlation in the short term and more } \\
\text { correlation in the long term. }\end{array}$ \\
\hline $\begin{array}{l}\text { Kendirli and } \\
\text { Çankaya } \\
(2016) \\
\end{array}$ & $\begin{array}{l}\text { 4 January } 2000- \\
30 \text { April } 2015 \\
\text { Granger Causality }\end{array}$ & Turkey & $\begin{array}{l}\text { BIST100 Index and Borsa Istanbul } \\
\text { Transportation Index are the reasons for crude } \\
\text { oil prices. }\end{array}$ \\
\hline $\begin{array}{c}\text { Zortuk and } \\
\text { Bayrak (2016) }\end{array}$ & $\begin{array}{c}\text { 2002: M4 - } \\
\text { 2014: M8, } \\
\text { Autoregressive } \\
\text { Distribution Lag } \\
\text { Test for Treshold } \\
\text { Cointegration }\end{array}$ & G7 Countries & $\begin{array}{l}\text { There is a cointegration relationship between } \\
\text { stock prices and oil prices. }\end{array}$ \\
\hline $\begin{array}{l}\text { Hu, Liu, Pan, } \\
\text { Chen and Xia } \\
\quad(2017)\end{array}$ & $\begin{array}{l}\text { 2004: M8-2016: } \\
\text { M8, } \\
\text { SVAR Model and } \\
\text { NARDL }\end{array}$ & China & $\begin{array}{l}\text { Shocks in oil prices have an impact on stock } \\
\text { prices both in the short and long term. }\end{array}$ \\
\hline $\begin{array}{l}\text { Salisu and Isah } \\
\quad(2017)\end{array}$ & $\begin{array}{l}\text { 2000: M1 - } \\
\text { 2015: M12, } \\
\text { Panel ARDL }\end{array}$ & $\begin{array}{l}5 \text { oil exporting } \\
\text { countries and } \\
8 \text { oil exporting } \\
\text { countries }\end{array}$ & $\begin{array}{l}\text { Stock prices react asymmetrically to changes } \\
\text { in oil prices in all countries. }\end{array}$ \\
\hline $\begin{array}{c}\text { Basher, Haug } \\
\text { and Sadorsky } \\
(2018)\end{array}$ & $\begin{array}{l}\text { 1974: M1 - } \\
\text { 2015: M8, } \\
\text { SVAR Model }\end{array}$ & $\begin{array}{l}8 \text { Oil } \\
\text { Exporting } \\
\text { Countries } \\
\end{array}$ & $\begin{array}{l}\text { Shocks in oil prices have a significant impact } \\
\text { on stock returns. }\end{array}$ \\
\hline $\begin{array}{c}\text { Elian and } \\
\text { Kisswani } \\
(2018)\end{array}$ & $\begin{array}{l}3 \text { January } 2000- \\
9 \text { December } 2015 \\
\text { (Daily data), } \\
\text { ARDL and Toda- } \\
\text { Yamamoto } \\
\text { Causality Test }\end{array}$ & Kuwait & $\begin{array}{l}\text { There is a bilateral causal relationship between } \\
\text { the two variables. }\end{array}$ \\
\hline $\begin{array}{l}\text { Naser and } \\
\text { Rashid } \\
(2018) \\
\end{array}$ & $\begin{array}{c}\text { 1991: M1 - } \\
\text { 2011: M3, } \\
\text { FAVAR Model }\end{array}$ & BRIC & $\begin{array}{l}\text { The response of stock prices to oil price shocks } \\
\text { is quite permanent and certain. }\end{array}$ \\
\hline $\begin{array}{c}\text { Al-Hajj, Al- } \\
\text { Mulali and } \\
\text { Solarin (2018) } \\
\end{array}$ & $\begin{array}{l}\text { 1990: M1 - } \\
\text { 2016: M11, } \\
\text { NARDL }\end{array}$ & Malaysia & $\begin{array}{l}\text { There is a long-term relationship between the } \\
\text { two variables. }\end{array}$ \\
\hline $\begin{array}{l}\text { Çitak and } \\
\text { Kendirli } \\
(2019) \\
\end{array}$ & $\begin{array}{c}\text { 2010: M1 - } \\
\text { 2019: M6, } \\
\text { NARDL }\end{array}$ & Turkey & $\begin{array}{l}\text { Oil prices does not have any impact on the } \\
\text { stock market returns in the long-run. }\end{array}$ \\
\hline Mokni (2020) & $\begin{array}{c}\text { 1999-2018 } \\
\text { (Montly data), } \\
\text { Structural VAR and } \\
\text { Time-Varying } \\
\text { Parameter } \\
\text { Regression Models }\end{array}$ & $\begin{array}{l}\text { Oil-Exporting } \\
\text { Countries }\end{array}$ & $\begin{array}{l}\text { Stock market returns show different responses } \\
\text { to oil shocks over time. }\end{array}$ \\
\hline $\begin{array}{c}\text { Ji, Liu, Zhao } \\
\text { and Fan } \\
(2020)\end{array}$ & $\begin{array}{l}\text { 1994: M2 - } \\
\text { 2016: M12, } \\
\text { SVAR Model }\end{array}$ & BRICS & $\begin{array}{l}\text { There is a significant spreading effect from oil- } \\
\text { specific demand shocks to stock returns. }\end{array}$ \\
\hline
\end{tabular}


Studies usually used monthly data except few exceptions (Abdullah et al., 2016; Broadstock et al., 2012; Elian and Kisswani, 2018; İşcan, 2010; Kendirli and Çankaya, 2016; Şener et al., 2013), were generally used in the studies. Most studies in the literature examining the relationship between stock prices and oil prices do not take structural breaks into account. However, studies that include both sharp and smooth structural shifts into model do not exist in the literature, although there exist studies considering sharp structural breaks (Le and Chang, 2015). Therefore, econometric methods that incorporate both sharp and smooth structural shifts in the model were preferred for this study.

\section{Econometric Methodology}

In this study, long-term relationship between stock prices and oil prices in Turkey were examined. In this context, the Fourier Shin Cointegration test recommended by Tsong et al. (2016) was used in the study. For the cointegration test, first the unit root properties of the variables should be examined. Therefore, the unit root properties of the variables were investigated by Fourier KPSS (Kwiatkowski-Phillips-Schmidt-Shin) unit root test first developed by Becker, Enders and Lee (2006). The FKPSS test, unlike other unit root tests, takes into account both sharp structural changes and smooth transition structural changes. Becker et al. (2006) consider the following data generation process:

$$
y_{t}=\alpha_{0}+\alpha_{1} \sin \left(\frac{2 \pi k t}{T}\right)+\alpha_{2} \cos \left(\frac{2 \pi k t}{T}\right)+\eta_{t}+\varepsilon_{t}
$$

where the $\eta_{t}$ process is described as:

$$
\eta_{t}=\eta_{t-1}+u_{t}
$$

where $\varepsilon_{t}$ are errors and $u_{t}$, are independent and identicaly distributed with variance $\sigma_{u}^{2}$. In addition to $k$ shows the optimal number of observations and $\pi$ is the constant (3.14).

Under the null hypothesis $\sigma_{u}^{2}=0$, so that the process described by eqn (1) is stationary. The test statistic is given by:

$$
\tau_{\mu}(k)=\frac{1}{T^{2}} \frac{\sum_{t=1}^{T} \tilde{S}_{t}(k)^{2}}{\tilde{\sigma}^{2}}
$$

where $\tilde{S}_{t}(k)=\sum_{j=1}^{t} \tilde{\varepsilon}_{j}$ and $\tilde{\varepsilon}_{j}$ are the OLS residuals from the Equation (1).

Becker et al. (2006) proposed that a nonparametric estimate of $\sigma^{2}$ be optained by choosing a truncation lag parameter $l$ and a set of weights $w_{j}, j=1,2, \ldots, l$ :

$$
\sigma^{2}=\tilde{\alpha}_{0}+2 \sum_{j=1}^{l} w_{j} \tilde{\alpha}_{j}
$$

where $\tilde{\alpha}_{j}$ is $j$ th sample autocovariance of the residuals $\tilde{\varepsilon}_{t}$ from equation (1). The optimal frequency $(k)$ number in Equation (1) is obtained by searching all frequencies from 1 to 5. Hence, the optimal number of frequency $(k)$ is selected using the value which gives the minimum sum of squares residuals. 
To test the significance of the Fourier components, Becker et al. (2006) suggest to use Ftest. The necessary critical values for both the FKPSS and F-tests are tabulated in Becker et al. (2006) (Y1lanc1, Aslan and Özgür, 2018).

In the second phase of the analysis, the FSHIN cointegration test was used. In the FSHIN cointegration test, the following model is used.

$$
y_{t}=d_{t}+x_{t}^{\prime} \beta+\eta_{t}
$$

where $\eta_{t}=\gamma_{t}+v_{1 t}, \gamma_{t}=\gamma_{t-1}+u_{t}$ with $\gamma_{0}=0$, and $x_{t}=x_{t-1}+v_{2 t}$. Here $\gamma_{t}$ is a random walk with mean zero. The deterministic component $d_{t}$ in Eq (5) is assumed as

$$
d_{t}=\sum_{i=0}^{m} \delta_{i} t^{i}+f_{t}
$$

with $m=0$ or $m=1$, and

$$
f_{t}=\alpha_{1} \sin \left(\frac{2 \pi k t}{T}\right)+\alpha_{2} \cos \left(\frac{2 \pi k t}{T}\right)
$$

The scalar $v_{1 t}$ and p-vector $v_{2 t}$ are stationary, and hence, $y_{t}$ and $x_{t}$ are all $\mathrm{I}(1)$ processes. Obviously, if $\sigma_{u}^{2}=0, \eta_{t}=v_{1 t}$ is a stationary process, implying that $y_{t}$ and $x_{t}$ are cointegration against the alternative of non-cointegration can be written as $H_{0}: \sigma_{u}^{2}=0$ versus $H_{1}: \sigma_{u}^{2}>0$. In order to be able to test the basic hypothesis of cointegration, equation (5) can be rewritten as:

$$
y_{t}=\alpha_{0}+\alpha_{1} \sin \left(\frac{2 \pi k t}{T}\right)+\alpha_{2} \cos \left(\frac{2 \pi k t}{T}\right)+x_{t}^{\prime} \beta+v_{1 t}
$$

where $k, t, T$ and $\pi$ are defined as before. The FSHIN test statistic can be obtained by using: $C I_{f}^{m}=T^{-2} \widehat{\omega}_{1}^{-2} \sum_{t=1}^{T} S_{t}^{2}$, where $S_{t}=\sum_{t=!}^{T} \hat{v}_{1 t}$ is the partial sum of the OLS residuals from Eq (8), and $\widehat{\omega}_{1}^{2}$ represents the consistent estimator for the long-run variance of $v_{1 t}$.

F-test is also used in FSHIN cointegration test to test the significance of Fourier components. If F-test is not statistically significant, SHIN cointegration test results proposed by Shin (1994) should be used since the Fourier components are not significant.

\section{Data and Empirical Findings}

\subsection{Data ${ }^{1}$}

Data set used in the study was taken from the Central Bank of Turkey and definitions are presented in Table 2. Natural logarithm of both variables was taken and included in the analysis. Daily data for the period of January 2, 2002 - July 2, 2019 were used.

Table 2. Variables Descriptions

\begin{tabular}{ll}
\hline Variable & Definition \\
\hline ln stockprice & Istanbul Stock Exchange National-100 Index (BIST100) \\
ln oilprice & Europe Brent Spot Price FOB (Dollars per Barrel) \\
\hline
\end{tabular}

\footnotetext{
${ }^{1}$ Ethics of research and publication were followed in this study, which does not require permission from the ethics committee and/or legal/special permission.
} 
The stock prices and oil prices used in the study are presented in Figure 1. The figures display an upward trend on oil prices until global crisis in 2008 and sharp decreases in prices in post-crisis period. As a result of the developments, so-called 'Arab Spring', started in 2010, oil prices increased once again. We observe that there occurred sharp declines in oil prices between 2014 and 2016 again. There are several reasons for this. The first cause is that China's energy demand decreased, depending on the fact that its growth rate slowed down during this period. Secondly, the oil supplied to the market in this period is higher than the demand. This is specifically caused by the fact that Saudi Arabia, the largest oil producer, refused to reduce its oil supply in this period. Thirdly, perhaps most importantly, the US appeared to be a country to meet its own energy needs [as oil and natural gas], just after it begins to produce a significant amount of oil and natural gas as a result of the US shale gas / shale oil revolution and investments in this period. Consequently, the downward trend in oil prices in general continued during the first months of 2016 as well. Russian and Saudi Arabian Energy Ministers, who want to reduce the negative effects of this circumstance for themselves, announced that they had decided to freeze the oil supply at the level of January 11 along with an agreement signed on 16 February 2016.
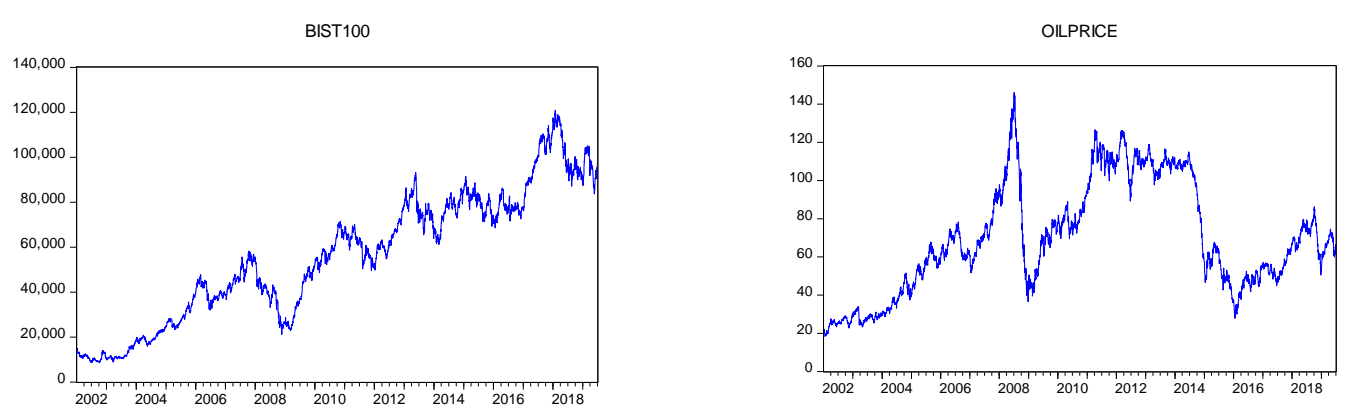

Figure 1. BIST100 and Oil Price (02/01/2002 - 02/07/2019)

Descriptive statistics of the data set used in the study are presented in Table 3. Accordingly, while the average stock price in Turkey was calculated as 55995.55 for the period taken, oil prices were at the level of $\$ 69.47$. When the standard deviation estimates examined, stock prices were more volatile than oil prices in the period under consideration. Jarque - Bera statistics reject the null hypothesis that assumes both variables are normally distributed. Therefore, both variables do not have characteristics to be normally distributed. This is expected when working with financial data.

Table 3. Descriptive Statistics

\begin{tabular}{lll}
\hline & stockprice & oilprice \\
\hline Mean & 55995.550 & 69.470 \\
Median & 56754.410 & 65.470 \\
Maximum & 120845.300 & 146.080 \\
Minimum & 8627.420 & 18.410 \\
Std. Dev. & 28653.140 & 28.947 \\
Jarque - Bera (Prob.) & $185.827(0.000)$ & $225.011(0.000)$ \\
Obs. & 4565 & 4565 \\
\hline
\end{tabular}




\subsection{Empirical Findings}

Before the analysis of the long-term relationship between stock prices and oil prices, the stationarity characteristics of both series were investigated. It is observed in Table 4 that both series are not stationary. Therefore, the difference between the two series was taken and the FKPSS test for stationarity was employed again. The F test, which provides the significance level of trigonometric terms, indicates that trigonometric terms in series the difference taken are not significant; for this reason, KPSS stationarity test was also applied to the series the difference taken. According to the findings obtained from this test, it is figured out that the difference between the two series becomes stationary. Therefore, both series are first order integrated I(1) series.

Table 4. Findings of Fourier KPSS Stationarity Test

\begin{tabular}{lrrrrr}
\hline Variables & FREQ & Min SSR & FKPSS & KPSS & $\boldsymbol{F}_{\boldsymbol{t}}$ \\
\hline ln stockprice & 1 & 405.687 & $1.171(53)$ & & $3152.68^{*}$ \\
ln oilprice & 1 & 1103.820 & $2.624(53)$ & & $2032.64^{*}$ \\
$\Delta \ln$ stockprice & 3 & 8543.49 & $0.275(5)^{*}$ & $0.088(13)^{*}$ & 2.083 \\
$\Delta \ln$ oilprice & 3 & 1.403 & $0.072(15)^{*}$ & $0.261(14)^{*}$ & 2.053 \\
\hline
\end{tabular}

Notes: $5 \%$ critical values for the F-KPSS: $=1 \Rightarrow 0.170$ freq $=3 \Rightarrow 0.439 .5 \%$ critical values for the $F_{t}$ are $4.651 .5 \%$ critical values for the KPSS are 0.463 . The values in parentheses indicate the bandwith width.

When series in Figure 2 are examined, it is observed that Fourier estimations of both series are appropriate and capture long oscillations on the series.

ln oilprice
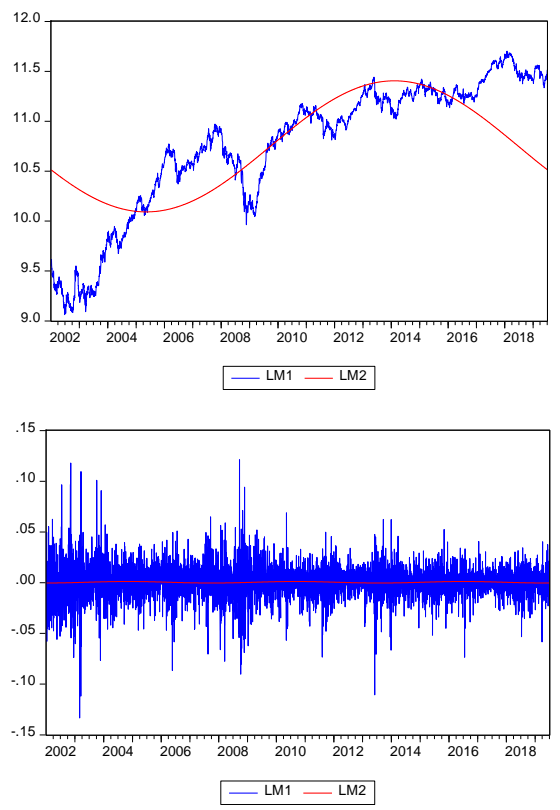

ln stockprice
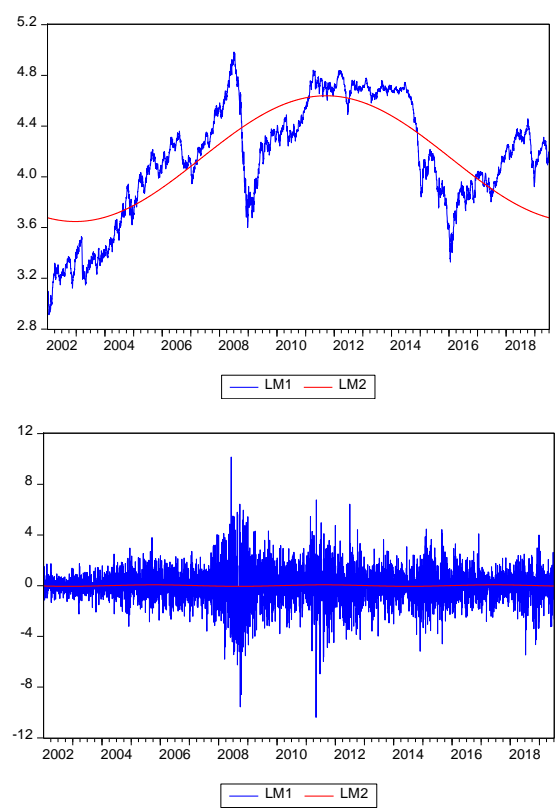

Figure 2. Variables and Fourier Functions 
Table 5. Findings of Fourier SHIN Stationarity Test

\begin{tabular}{rrrrr}
\hline FREQ & Min SSR & FSHIN & SHIN & $\boldsymbol{F}_{\boldsymbol{t}}$ \\
\hline 2 & 220.653 & 0.197 & 1.741 & $8.019^{*}$ \\
\hline
\end{tabular}

Notes: $5 \%$ critical values for the Fourier SHIN cointegration test for frequencies 2 are $0.182 .5 \%$ critical values for the SHIN cointegration test are $0.314 .5 \%$ critical values for the $F_{t}$ are 4.066 . (*) notation represents significance in $5 \%$.

The long-term relationship between stock prices and oil prices was examined by both FSHIN and SHIN cointegration tests. Findings for Cointegration Test are given in Table 5. Fourier components, trigonometric terms, are significant as the $\mathrm{F}$ test is statistically significant. Therefore, FSHIN cointegration test findings can be interpreted. However, both FSHIN cointegration test findings and SHIN cointegration test results indicate that there exists no longterm relationship between the two variables. Accordingly, sudden changes in oil prices do not have any long-term impact on stock prices. Finally, the findings obtained in this study, are compatible and parallel with those obtained by Apergis and Miller (2009), Arouri et al. (2011), Gay (2008) and İşcan (2010).

\section{Conclusions}

In this study, the impact of oil prices on stock prices in Turkey by making use of the Fourier SHIN cointegration test developed by Tsong et al. (2016). Findings obtained indicate there exists no significant long-term relationship between the two variables, considering the sharp and soft fractures as well. Accordingly, we can conclude that oil prices are not among the determinants or predictors of stock prices in the long run. Therefore, both variables do not move together in the long run. When a long-term investment decision is taken for investors, oil prices may not be considered as an important indicator in the decision-making process for the BIST100 index. However, the relationship between the two variables in sectors where oil is an important input can be examined in future studies.

On the other hand, the change in oil prices may have a better effect on the inflation rate. In this case, the inflation rate may have a deeper and a stronger impact on stock prices. From the investors' point of view, it will be useful and functional for them to examine other macroeconomic variables as they do not prioritize the movements in oil prices during the decision-making process. Because, the findings additionally indicate that other national and international macroeconomic variables (such as production, inflation, interest rate, foreign trade balance) may be determinant on stock prices. In this case, further investigation is required regarding the relationship between other macroeconomic variables and stock prices.

Researchers' Contribution Rate Statement

I am a single author of this paper. My contribution is $100 \%$.

\section{Conflict of Interest Statement}

There is no potential conflict of interest in this study. 
M. Songur, “A Review on the Relationship Between Oil Prices and Stock Prices in Turkey:

New Evidences from Fourier Approach"

\section{References}

Abdullah, A. M., Saiti, B. and Masih, M. (2016). The impact of crude oil price on Islamic stock indices of South East Asian Countries: Evidence from MGARCH-DCC and wavelet approaches. Borsa Istanbul Review, 16(24), 219-232. doi:10.1016/j.bir.2015.12.002

Al-hajj, E., Al-Mulali, U. and Solarin, S. A. (2018). Oil price shocks and stock returns nexus for Malaysia: Fresh evidence from nonlinear ARDL test. Energy Reports, 4, 624-637. doi:10.1016/j.egyr.2018.10.002

Apergis, N. and Miller, S. M. (2009). Do structural oil-market shocks affect stock prices?. Energy Economics, 31(4), 569-575. https://doi.org/10.1016/j.eneco.2009.03.001

Arouri, M. E. H., Bellalah, M. and Nguyen, D. K. (2011). Further evidence on the responses of stock prices in GCC countries to oil price shocks. International Journal of Business, 16(1), 89-102. Retrieved from https://www.craig.csufresno.edu

Basher, S. A. and Sadorsky, P. (2006). Oil price risk and emerging stock markets. Global Finance Journal, 17(2), 224-251. doi:10.1016/j.gfj.2006.04.001

Basher, S. A., Haug, A. A. and Sadorsky, P. (2018). The Impact of oil-market shocks on stock returns in major oil-exporting countries. Journal of International Money and Finance, 86, 264-280. doi:10.1016/j.jimonfin.2018.05.003

Becker, R., Enders, W. and Lee, J. (2006). A stationary test in the presence of an unknown number of smoot breaks. Journal of Time Series Analysis, 27(3), 381-409. doi:10.1111/j.14679892.2006.00478.x

British Petroleum. (2019). BP statistical review of world energy 2019. Retrieved from https://www.bp.com

Broadstock, D.C., Cao, H. and Zhang, D. (2012). Oil shocks and their impact on energy related stocks in China. Energy Economics, 34(6), 1888-1895. doi:10.1016/j.eneco.2012.08.008

Burbidge, J. and Harrison, A. (1984). Testing for the effects of oil-price rises using vector autoregressions. International Economic Review, 25(2), 459-484. Retrieved from https://www.jstor.org

Çıtak, F. and Kendirli, S. (2019). Petrol fiyatlarinin döviz kuru ve hisse senedi getirileri üzerindeki asimetrik etkisi: Türkiye örneği [Asymmetric impact of oil prices on exchange rate and stock prices: The case of Turkey]. Finans Ekonomi ve Sosyal Araştırmalar Dergisi (FESA), 4(4), 643658. Retrieved from https://dergipark.org.tr/tr/pub/fesa

Cong, R. G., Wei, Y. M., Jiao, J. L. and Fan, Y. (2008). Relationships between oil price shocks and stock market: An empirical analysis from China. Energy Policy, 36(9), 3544-3553. doi:10.1016/j.enpol.2008.06.006

Cunado, J. and Gracia, F. P. (2014). Oil price shocks and stock market returns: Evidence for some European countries. Energy Economics, 42, 365-377. doi:10.1016/j.eneco.2013.10.017

Elian, M. I. and Kisswani, K. M. (2018). Oil price changes and stock market returns: cointegration evidence from emerging market. Economic Change and Restructuring, 51(4), 317-337. doi:10.1007/s10644-016-9199-5

Gay, R. D. Jr. (2008). Effect of macroeconomic variables on stock market returns for four emerging economies: Brazil, Russia, India and China. International Business and Economics Research Journal, 7(3), 1-8. doi:10.19030/iber.v7i3.3229

Gisser, M. and Goodwin, T. H. (1986). Crude oil and the macroeconomy: Tests of some popular notions: note. Journal of Money, Credit and Banking, 18(1), 95-103. Retrieved from https://www.jstor.org

Hamilton, J. D. (1983). Oil and macroeconomy since World War II. The Journal of Political Economy, 91(2), 228-248. Retrieved from https://www.jstor.org 
Hu, C., Liu, X., Pan, B., Chen, B. and Xia, X. (2018). Asymmetric impact of oil price stock market in China: A combination analysis based on SVAR model and NARDL model. Emerging Markets Finance and Trade, 54(8), 1693-1705. doi:10.1080/1540496X.2017.1412303

İşcan, E. (2010). Petrol fiyatlarının hisse senetleri üzerindeki etkisi [The impact of oil prices on stock prices]. Maliye Dergisi, 158, 607-617. Retrieved from https://www.hmb.gov.tr/maliye-dergisiduyurular

Ji, Q., Liu, B. Y., Zhao, W. L. and Fan, Y. (2020). Modelling dynamic dependence and risk spillover between all oil price shocks and stock market returns in the BRICS. International Review of Financial Analysis, 68, 1-12. doi:10.1016/j.irfa.2018.08.002

Kendirli, S. and Çankaya, M. (2016). Ham petrol fiyatlarının BİST 100 ve BİST ulaştırma endeksleri ile ilişkisi [Relationship between crude oil prices with BİST 100 index and BİST transportation index]. Kastamonu Üniversitesi İktisadi ve İdari Bilimler Fakültesi Dergisi, 12(2), 136-141. Retrieved from https://dergipark.org.tr/tr/pub/iibfdkastamonu

Le, T-H. and Chang, Y. (2015). Effects of oil price shocks on the stock market performance: Do nature of shocks and economies matter?. Energy Economics, 51, 261-274. https://doi.org/10.1016/j.eneco.2015.06.019

Maghyereh, A. and Al-Kandari, A. (2007). Oil prices and stock markets in GCC countries: New evidence from nonlinear cointegration analysis. Managerial Finance, 33(7), 449-460. doi:10.1108/03074350710753735

Mokni, K. (2020). Time-varying effect of oil price shocks on the stock market returns: Evidence from oilimporting and oil-exporting countries. Energy Reports, 6, 605-619. doi:10.1016/j.egyr.2020.03.002

Naser, H. and Rashid, A. (2018). Oil price shocks and stock market performance in the BRICs: Some evidence using FAVAR models. Economics Issues, 23(2), 85-108. doi:10.20547/jfer1904201

Park, J. and Ratti, R. A. (2008). Oil price shocks and stock markets in the U.S. and 13 European Countries. Energy Economics, 30, 2587-2608. doi:10.1016/j.eneco.2008.04.003

Sadorsky, P. (1999). Oil price shocks and stock market activity. Energy Economics, 21(5), 449-469. doi:10.1016/S0140-9883(99)00020-1

Salisu, A. A. and Isah, K. O. (2017). Revisiting the oil price and stock market nexus: A nonlinear panel ARDL approach. Economic Modelling, 66, 258-271. doi:10.1016/j.econmod.2017.07.010

Şener, S., Yılancı, V. and Tıraşoğlu, M. (2013). Petrol fiyatları ile Borsa İstanbul'un kapanış fiyatları arasındaki saklı ilişkinin analizi [Analyzing the hidden cointegration between oil prices and stock prices]. Selçuk Üniversitesi IIBF Sosyal ve Ekonomik Araştırmalar Dergisi, 26, 231-248. Retrieved from https://dergipark.org.tr/tr/pub/susead

Shin, Y. (1994). A residual-based test of the null of cointegration against the alternative of no cointegration. Econometric Theory, 10(1), 91-115. Retrieved from https://www.jstor.org

Tsong, C. C., Lee, C. F., Tsai, L. J. and Hu, T. C. (2016). The Fourier approximation and testing for the null of cointegration. Emprical Economics, 51(3), 1085-1113. doi:10.1007/s00181-015-1028-6

Ünlü, U. and Topcu, M. (2012). Do oil prices directly affect stock markets: Evidence from Istanbul Stock Exchange. İktisat Işletme ve Finans, 27(319), 75-88. Retrieved from www.iif.com.tr

Yılancı, V., Aslan, M. and Özgür, Ö. (2018). Testing the validity of PPP theory for African Countries. Applied Economics Letters, 25(18), 1273-1277. doi:10.1080/13504851.2017.1418066

Zortuk, M. and Bayrak, S. (2016). Ham petrol fiyat şokları-hisse senedi piyasası ilişkisi: ADL eşik değerli koentegrasyon testi [The relationship between crude oil price shocks and stock prices: ADL threshold cointegration test]. Eskişehir Osmangazi Üniversitesi IIBF Dergisi, 11(1), 7-22. Retrieved from https://dergipark.org.tr/tr/pub/oguiibf 